\title{
Quality of Scots Pine Pollen Depending on the Aerotechnogenic Pollution Level with Emissions from Reftinskiy GRES Power Plant
}

\author{
Svetlana Makhniova, Nadezhda Kuzmina, Sergey Menschikov \\ Botanical Garden, Ural Branch of Russian Academy of Sciences, Yekaterinburg, Russia \\ Email: makhniovasg@mail.ru
}

How to cite this paper: Makhniova, S., Kuzmina, N. and Menschikov, S. (2017) Quality of Scots Pine Pollen Depending on the Aerotechnogenic Pollution Level with Emissions from Reftinskiy GRES Power Plant. Journal of Geoscience and Environment Protection, 5, 99-117.

https://doi.org/10.4236/gep.2017.54009

Received: February 27, 2017

Accepted: April 22, 2017

Published: April 25, 2017

Copyright $\odot 2017$ by authors and Scientific Research Publishing Inc. This work is licensed under the Creative Commons Attribution International License (CC BY 4.0).

http://creativecommons.org/licenses/by/4.0/

(c) (i) Open Access

\begin{abstract}
The aim of the current study was to investigate the process of microgametogenesis and diagnostic of condition of the Pinus sylvestris male generative system in the tree stands exposed to the influence of Reftinskiy GRES power plant (RGpp) emission during ontogenesis in connection with the level of technogenic pollution. It was detected that in the impact area, smoke emissions from the RGpp in the south-west direction zones of technogenic pollution were formed. Those vary in qualitative composition of the snow pack pollutants and their quantitative characteristics. The content of water insoluble compounds in melt snow water and the compile suspended matter, decreases regularly at the longer distance from the source of air pollutants. The highest content of water soluble compounds in the melt snow water was indicated at the distances of 5, 8 and $14 \mathrm{~km}$ from the source of air pollutants, authentically lower in the nearest and farthest sampling points of the snow trials. Scots pine (Pinus sylvestris) pollen significative with high prognostic value in relation to the level of toxic load upon the eco-systems and the condition of male generative system were discovered. It was detected that the significative meanings of pollen with morphological abnormalities decreased, and the meanings of functional significatives increased at the longer distance from the source of air pollutants. Pollen fertility, pollen tube length and reserve substances content significative is negatively related to the presence of micro and macro elements in the snow water; those identify the toxic load level on the ecosystem probably to the highest degree. Pine male gametophyte elimination, while forming in the impact zone of the GRES power plant, takes place at the stage of pollen grain germination as well as pollen tubes' growth stage.
\end{abstract}

\section{Keywords}

GRES Power Plant, Pollen Grain Anomalies, Scots Pine, 
Technogenic Pollution

\section{Introduction}

In Russia, $68 \%$ in the structure of electric power production is accounted for by thermal electric power stations, [1] that provides basic needs of electric power in the country. One of the main disadvantages of the thermal power is its insecurity for the environment. Thermal electric power stations contribute a lot to the pollution of all environmental components: air, soil, water [2] [3] [4] [5]. In Russian Federation in 2014, 21.6\% of emissions into the open air from all stationary pollution sources accounted for by production and distribution plants of electric power, gas and water [6].

Reftinskiy GRES power plant (RGpp) is one of the large-scaled thermal power plants of Russia and is the largest Russian GRES power plant fueled by coal. RGpp mainly uses Ekibastuz coal that features high ash content on dry basis43.3\%, and high content of micro elements in the ash dust [7]. For instance, in production of $1 \mathrm{~kW} \cdot \mathrm{h}$ electric power, the content of $\mathrm{Cd}$ is $13.2, \mathrm{Ni}-11.1$, $\mathrm{Pb}-8.7$ times as high in comparison to the ash of Kansk-Achinsk coal basin. According to the 2014 year data, every year RGpp disposes more than 4 mln.tones of ash and refuse burnout to the ash-disposal area [8]. Ash-disposal area dusting is an additional factor of the open air pollution. Ash-disposal area №1 that numbers 440 ha is put out of operation and completely reclaimed [9]. Nowadays, ash-disposal area №2 that counts 1008 ha is in operation of GRES power plant. RGpp disposes 144.48 thousand tones of ash dust into the atmosphere annually, 315.4 thousand tones of the pollutants that compile $30.9 \%$ from the total emission of plants and factories across the region [7] [8]. During last years, flux of gas release into the atmosphere from GRES power plant has increased. So, in 1995, their volume compiled 155.4 thousand tones per year, including 90.9 thousand tones of $\mathrm{SO}_{2}$, then in 2010, it compiled 145.4 thousand tones per year [10] [11]. Thus, RGpp is the largest environment polluter across the region.

The most part of the smoke emission from the RGpp is received by the forests in the area. According to the literature data, technogenic stress originating from the current impact of the atmospheric air pollutants, those are substances accumulated in the soil, and also, transformed habitat conditions influence plants. It was indicated that gas releases can influence acerose leaf directly [12] [13]. Soluble substances in the precipitation coming with the rains also affect the acerose leaf and are able to mobilize in soil and act upon root system to the extent of drying out and damage of the assimilatory apparatus [10] [14] [15]. It was indicated that conifers accumulate heavy metals, sulphates, polynuclear aromatic hydrocarbons, fluorides in the acerose leaf, branches, woody tissue and roots [10] [14] [16] [17]. Accumulation of pollutants in plant can cause reduction of tree viable condition, needle packing and acerose leaf lifetime [10] [14], cause 
changes of pigmental system and anatomic-morphological characteristics of acerose leaf [18]. The degree of chemical substances accumulation may be dued to their presence in soil, availability, and also, their participation in normal vital function of the plants [10] [19].

The results of many studies confirm unfavourable impact of technogenic pollution on the plant reproduction. According to the literature data, the amount of abnormal pine pollen increases under the conditions of the technogenic pollution [20]-[26]. High level of heavy metals accumulation and other elements in the pollen can be considered as one of the factors of increase in frequency of plants' imperfectly formed pollen [24] [26] [27] [28]. Particular authors remark correlation between the presence of the substances in the soil and the condition of the pollen [29], the presence of in the acerose leaf and the pollen fertility [30]. Formation of the male gametophyte is one of the key stages in pine's reproduction that makes it an important subject of biomonitoring. However, there is a lack of data concerning the correlation of pollen quality and presence of metal compounds in the elements of ecosystems, and quite often it is contradictory, that prevents understanding of damage and sustainability mechanisms in the generative system of perennial plants. The information about the influence of atmospheric pollution GRES power plant with dominant ash component on conifers reproduction is also poor.

The study of Scots pine (Pinus sylvestris) generative system in the area of aerotechnogenic pollution by RGpp was initiated in 2013-2014 years. The area under research is located in Neyvo-Lozvinsk piedmont forest growing province of West Siberian wooded area [31]. The climate of the region is moderate continental; the soil of pine forest on the drained forest territories is mountain forest bleached soil. Scots pine predominates in the tree stands nearabout the GRES power plant; the age of natural tree stands is 90 - 130 years; the type of forest is the grass pine forest; all tree stands feature high productivity and high density [10].

Scots pine traditionally becomes the subject of monitoring researches due to its extended habitat, economic value and technogenic pollution vulnerability. Nevertheless, a number of questions concerning pine reproduction are left insufficiently explored. GRES Aerosol emissions complexity, possibility of their release through the large distance and irregularity of fallouts and alsolong-term period of pine male gametophyte are that field of research, where the problems of diagnostic of the reproduction condition and environment technogenic pollution bioindication should be solved.

The aim of the current study was to investigate the process of microgametogenesis and diagnostic of condition of the Scots pine (further-pine) male generative system in the tree stands exposed to the influence of RGpp emission during ontogenesis in connection with the level of technogenic pollution.

Results of complex qulitative and quantitative evaluation of specie-edificator biological changes under the influence of air pollution with aeropollutants and evaluation of their crucial meaning (significance) for the species reproduction 
are the practical basis for the technogenic pollution biomonitoring, identifying of bions sustainable and unsustainable to the stress factor, understanding of pollutant matters transformation regularities in the plant and mechanisms of affection and adaptation in the pine trees, including setting into selection.

\section{Material and Methods}

The research of the male generative system of the Scots pine was held in the sample areas (SA) laid at a distance of $2 \mathrm{~km}$ (SA-1), $5 \mathrm{~km}$ (SA-2), $9 \mathrm{~km}$ (SA-3), $15 \mathrm{~km}$ (SA-4) from the source of technogenic pollution in the south-west direction (Figure 1). South-east and east directions from the RGpp are the most polluted; the tree stands in those directions have the status of medium and weakly damaged [10]. Particular interest for the research is presented in the tree stand at the distance of $2 \mathrm{~km}$ from GRES power plant (SA-1). The tree stand is presented with the Scots pine crop set in 1992 on the RGpp ash-disposal area №1 by the staff members of Institute Botanic Garden UB RAS (previous Institute of Forest UB RAS). Plantings of the two-year old pine (first 7 lines on the recultivated area) were conducted as the trench digging with placement of clayey soil and peat mixture into the furrows of $0.25 \mathrm{~m}$ depth [9]. At the present time, the pine crops are passing into the reproductive stage that allowed starting the study of the male generative system, seeds and seed geniture. Other SA was set in the natural tree stands. For obtaining data comparable with SA-1 the key features in the choice of the tree stands were the age of the tree stand (2nd class), crown exposition, forest growing conditions, and also presence of micro and macrostrobila on the trees while setting SA in the pollution gradient. 52 trees were included onto our study all together. More than 50 thousand of pollen grain sand more than 8.5 thousand of pollen tubes were examined.

\subsection{Methods for Determining the Level of Technogenic Pollution}

The level of SA technogenic pollution was determined by the research results of the snow pack pollution. The sample selection of the snow for the chemical analysis was performed on the 6 discount areas, four of them (1 - 4) were located on the SA stated earlier, their numbers corresponds to the numbers of the sam-
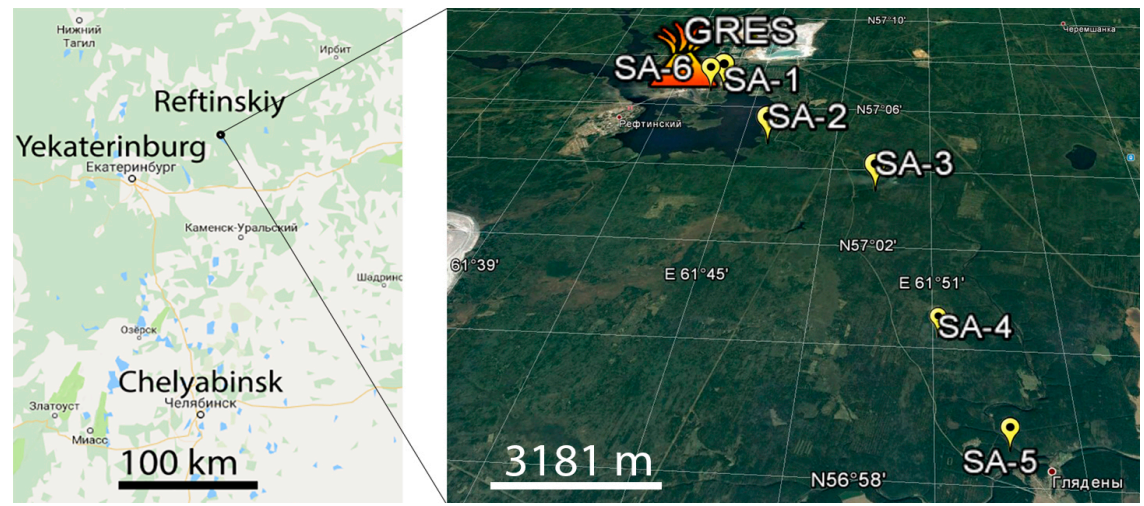

Figure 1. Location of the sample areas (SA). 
ple areas; discount area 5-at the distance of $19 \mathrm{~km}$ in the south-west direction from GRES power plant (SA-5) in the tree stand of the 3rd age class; discount area 6 -at the distance of $1 \mathrm{~km}$ in the east direction (SA-6) in the tree stand of the 6th age class (Figure 1). Snow cores were picked in March before the beginning of the snow melt. The samples were taken with the plastic tube set at the full depth of the snow pack, placed into the plastic bags and delivered to the laboratory. Melt snow water (further-snow water) was filtered. The meaning of the snow water $\mathrm{pH}$ level was measured with device Ionomer I-160M. Correspondingly, the weight of dry residue and suspended substance and also presence of metals $\left(\mathrm{gr} / \mathrm{m}^{2}\right)$ in their composition were measured in the snow water filtered material and residuum on the filter [32].

The content of dry feces and suspended matter were determined with the gravimetric method. Snow water suspended substance characterizes the concentration of water insoluble fractures of the polluting substances. For determination of the suspended matter snow water was filtered with the paper filter "white tape", than the filter was dried under the temperature $105^{\circ} \mathrm{C}$ until constant weight in the drying chamber, cooled in the exsiccator and weighed. Knowing filter weight before and after the procedure, the content of water insoluble substances on the filter was calculated. Knowing the volume of the filtered material, concentration of the suspended matter (gr/l) was calculated using the formula:

$$
X_{1}=\left(m_{2}-m_{1}\right) / V \text {, }
$$

where $m_{1}$-filter weight before the filtration, gr; $m_{2}$-filter weight after the filtration, gr; $V$-volume of the filtered water, liter.

For the calculation of the toxic load on the ecosystem $(Y)$ the acquired results were transferred into $\mathrm{gr} / \mathrm{m}^{2}$ using formula:

$$
Y_{1}=\left[X_{1} \cdot 10000 / S\right] \cdot V \text {, }
$$

where $X_{1}$-concentration of the suspended matter, gr/l, $S$-tube cross section area for gathering snow samples, $\mathrm{m}^{2}, V$-volume of the filtered water, liter.

Dry feces characterizes the content of deluted non-volatile mineral and organic substances, which boiling point is above $105^{\circ} \mathrm{C}-110^{\circ} \mathrm{C}$. For determination of the dry feces snow water $(50 \mathrm{ml})$ was evaporated in the porcelain cups under the temperature $103^{\circ}-105^{\circ}$, then it was dried in the drying chamber until the constant weight. Cups' weightment was performed on the analytical scales with inaccuracy of measurements not more than $\pm 0.01 \mathrm{mgr}$.

The dry feces concentration (gr/l) was calculated according to the formula:

$$
X_{2}=\left(m_{2}-m_{1}\right) \cdot 20 \text {, }
$$

where $m_{1}$-empty cup weight, gr; $m_{2}-$ cup weight with the feces, gr.

After that to calculate the toxic load $(Y)$ acquired result $X$ was transferred into $\mathrm{gr} / \mathrm{m}^{2}$ using formula:

$$
Y_{2}=X_{2} \cdot 10000 / S \text {, }
$$

where $X_{2}$-dry feces concentration, gr/l, $S$-tube cross section area for gathering snow samples. 
Metal concentration in the snow water dry feces and suspended substance $\left(\mathrm{gr} / \mathrm{m}^{2}\right)$ was determined with atomic absorption spectrophotometer novAA 300 (AnalitikJena, Germany).

\subsection{Methods of Studying the Quality of Pollen}

Pine microsrtobila were picked from all forming trees in the sample area in the beginning of June directly before the pollen dispersion, put into paper bags separately fro each tree. Microsrtobila were dried under the indoor conditions until the microsporangium dehiscence and pollen falling out. Fallen out pollen was collected into the paper bags and stored in the exsiceator under the temperature $+4^{\circ} \mathrm{C}$. Cytomorphological and functional traits of the mature pollen were studied [20] [33].

Pollen fertility was identified with the acetocarmine pigmentation of dry mature pollen under the heating. The pollen was considered as fertile if it had no visual features of damage to its elements structure and cytoplasm, had two air pockets, two adequately developed cells (vegetative and generative) and reserve substances in the cytoplasm of the vegetative cell. The following types of pollen grains anomalies were distinguished: microspores and pollen grains retarded from the basic mass of the tree pollen in the developmental stage and the level of reserve substances accumulation; pollen grains of the typical form and size with cytological distortions of the vegetative and/or generative cell; cytologically normal or with cytological and/or morphological distortions small-sized pollen grains (aneuploid, abortive or retarded); pollen grains with amount, size, shape anomalies of the air pockets; diads, tetrads; degenerated pollen grains (the sum of all morphologically normal and abnormal pollen grains with cytological distortions). The amount (\%) of all the abnormal pollen types from the sterile and examined pollen was measured. The content of the reserve substances (starch and lipids) was defined histochemically with Lugol's reagent and sudan, correspondingly (in scores). Also, the amount of pollen grains (\%) featured with high (3 - 4 scores) and not less than medium ( 2 and more scores) level of the starch accumulation.

For identifying functional adequacy of the male gametophyte mature pollen was couched in the distilled water on the slides with a ground cell in the humid chamber (Petri dish with lid) under the temperature $+27^{\circ} \mathrm{C}$ in the constant climate chamber. On the third day of the trial, pollen germination significatives (\%), the length of the pollen tube $(\mathrm{mkm})$, pollen tube germinating power (scores) were measured: from score-low(died) to 4-high. Also, the level of pollen tube branching and floccus development on the millieu (in numbers) were measured, according to the scheme from 1-no branching/fungus development to 4maximal branching/fungus development; the meaning of these significatives, close to 1 , indirectly shows to high germinating power of the pollen tubes. All examinations were performed with 3 - 5 times replication using AxioScope microscope, Sanyo MLR-351H constant climate chamber. Empirical data was processed with descriptive statistics, correlation analysis and nonparametric criteria 
methods; cluster, factor multivariate statistics methods (programme pack Statistica 6 for Windows).

\section{Result and Discussion}

\subsection{Technogenic Pollution Level of the Snow Pack in the Sample Areas}

Content of the chemical substances in the snow water objectively represents the level of the technogenic pollution of the territory, since continuously snow pack acts as an accumulator of aerosolic fallouts from the various sources. For this reason chemical analysis of the snow water is often applied for qualitative and quantitative evaluation of technogenic load on the ecosystems.

The results of the snow water composition examination are represented on Figures 2-4. It was determined that content of suspended substance in the snow water reduces regularly with the distance from the source of the technogenic pollution and set the pollution gradient (Figure 2).

Figure 3 shows concentration meanings of iron, manganese and zinc, those prevail in the snow water suspended matter composition in all SA; among the microelements nickel, chrome, lead are found.

Suspended substance weight in snow water correlates to the presence of manganese, iron, copper, chrome, nickel and cobalt ions in it $(r=0.47-0.95)$ (here

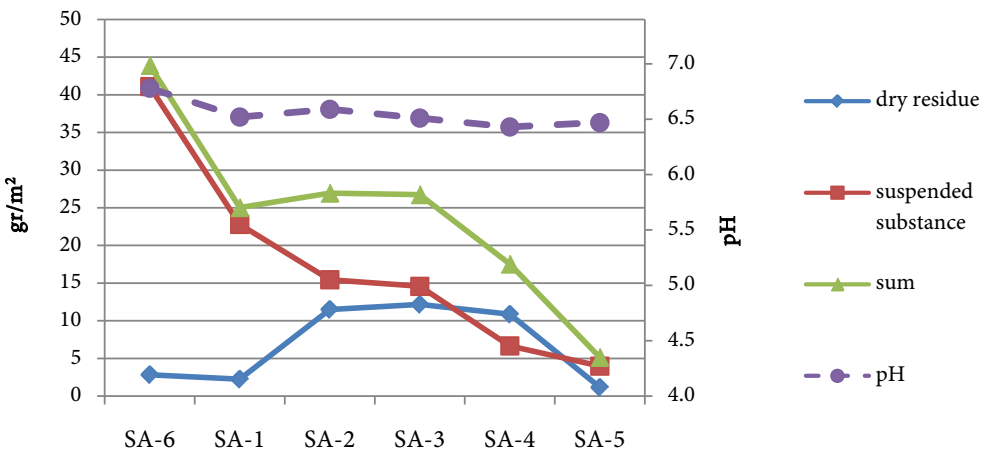

Figure 2. Snow water $\mathrm{pH}$ meanings, content of the dry residue and suspended substance $\left(\mathrm{gr} / \mathrm{m}^{2}\right)$ in it (here and further: scale for the dotted lines is on-scale of the auxiliary $y$ axis).

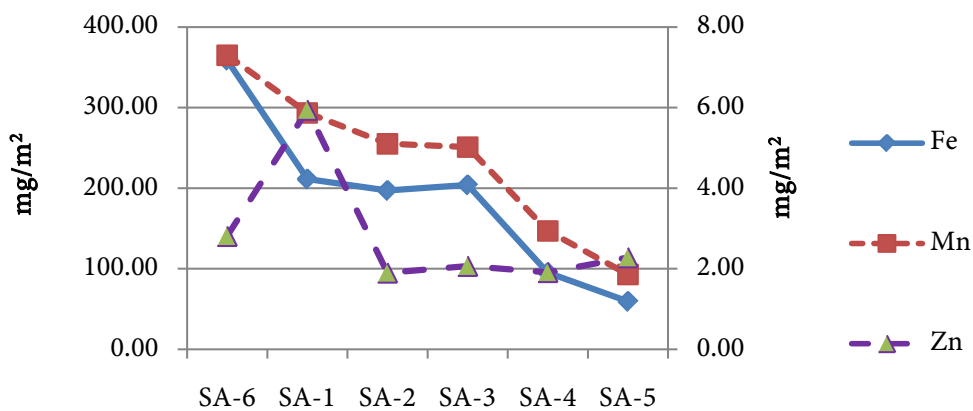

Figure 3. Content of the iron, manganese, zinc ions in the snow water suspended substance. 


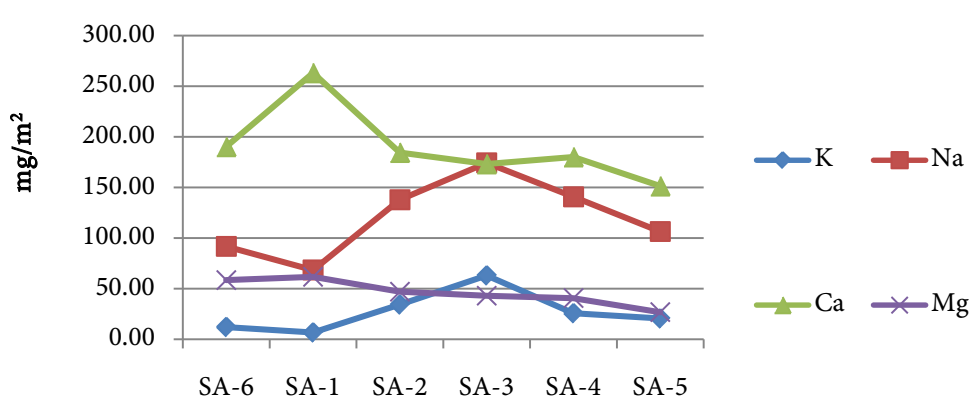

Figure 4. Content of the macroelements in the snow water filtered material.

and further authentically valid $\mathrm{r}$ meanings are shown with $\mathrm{p}<0.05)$. Content of the stated elements and, also, zinc compounds in the insoluble fraction of the snow water significantly decrease at the increasing distance from the source of the air pollutants.

The dry residue characterises fraction of the pollutants soluble in the snow water. It was indicated that the content of the dry residue in the snow water filtered material is higher at the distance of 5,9 and $14 \mathrm{~km}$ from the source of the air pollutants, authentically lower (by 4.3 - 10.4 times) -in the nearest and the farthest sampling points of the snow trial (1 - $2 \mathrm{~km}, 19 \mathrm{~km}$ ) (see Figure 2).

Mainly, the potassium, sodium, calcium, magnesium compounds and also compounds of iron, manganese, zinc contribute to the dry residue content in all SA (Figure 4). Correlation with the dry residue content is identified for the ions of sodium, potassium, manganese, nickel and cadmium $(r=0.37-0.51)$, and correlation with the distance from the air pollutants source for the $\mathrm{Mg}(\mathrm{r}=-0.55)$ and cadmium $(\mathrm{r}=0.60)$ compounds.

According to the sum of soluble and insoluble substances the highest level of the pollutants content was identified in the snow sample at the distance of $1 \mathrm{~km}$ from GRES power plant, the lowest-14 - $19 \mathrm{~km}$ (see Figure 2). The $\mathrm{pH}$ index meaning of the snow water in all SA varies $6.43-6.78$ (see Figure 2). The $\mathrm{pH}$ index of snow decreases with distance from the source of air pollutants $(\mathrm{r}=$ -0.61 ). Thus, the tendency of decreasing level of the snow technogenic pollution is with the distance from the source of air pollutants.

Results of the snow water chemical composition analysis with Mann-Whitney method allowed us to determine the level of differences between the SA, while their paired comparison. It is worth mentioning that SA at the distance of 14 and $19 \mathrm{~km}$ varies from the others $31 \%-55 \%$ and $48 \%-66 \%$ of the significatives, correspondingly. The least differences (in $17 \%$ and $34 \%$, correspondingly) were noticed in the pairs SA-2 - SA-3 and SA-3 - SA-4. In virtue of the cluster analysis results of the significatives complex, those characterise the level of the technogenic pollution SA (Figure 5), we distinguished 3 clusters and corresponding pollution zones: impact zone (SA-6 - SA-1), buffer (SA-2 - SA-3), background (SA-4 - SA-5). Authentically meaningful differences between the zones were defined through the content of magnesium in the snow water filtered material ( $\mathrm{p}=$ $0.050)$, manganese $(p=0.024)$, copper $(p=0.055)$ and nickel $(p=0.026)$ in the 


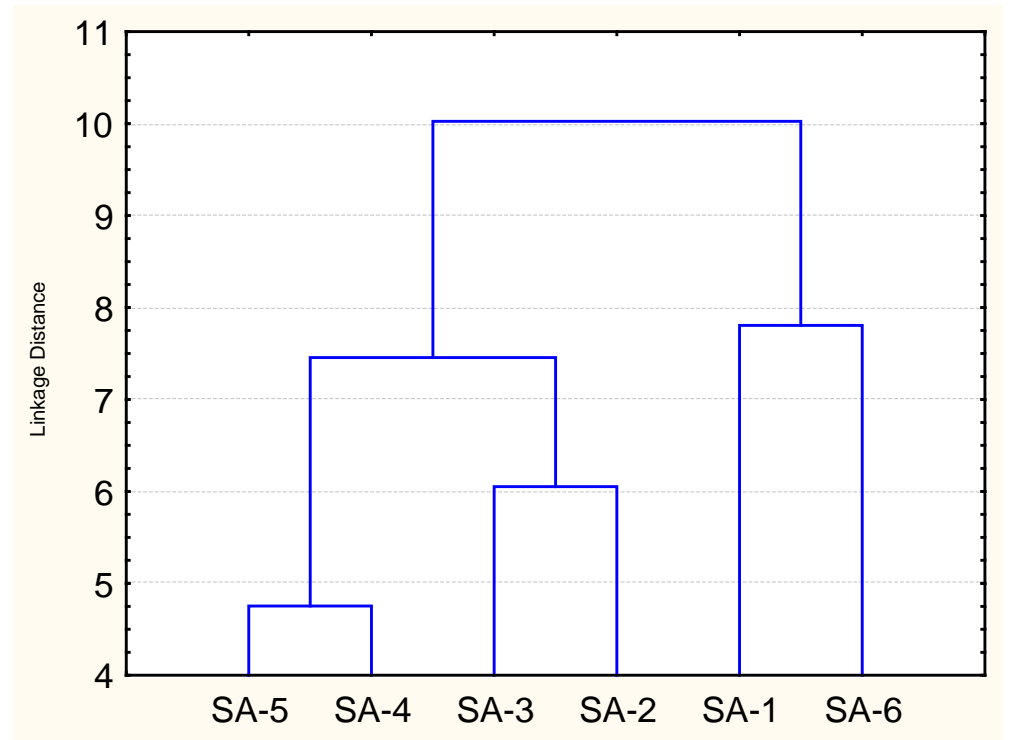

Figure 5. Results of the cluster analysis.

snow water solid fracture.

Thus, zones of the technogenic pollution different in the qualitative and quantitative characteristics are forming in the smoke emissions area of RGpp in the south-west direction.

The level of the technogenic pollution in the GRES power plant nearabout territories could be under the influence of several factors. It is known that distribution of the elements in the coal combustion products depends on their form present in the precursor, the composition of the mineral fracture and ash content of the coal and, also, the presence of other elements in the precursor coal [34] [35]. From 10 (aluminium, iron, manganese, sodium and others) to $100 \%$ (arsenium, bromine, mercury and others) of the total weight of compound elements enter the atmosphere during coal incineration [36]. Heavy substances of the air pollutants precipitate onto the nearest to the source of emission territories [2] [7] [35]. Metals with high gaseous mobilisation potential condensate on the drift ash particles during fuel incineration [7] [35] [37]. Submicron particles of the smoke gases enriched in heavy metals and organic substances in active form stay longer in the atmosphere and drift for the longer distances from the source than micron particles and, precipitating, accumulate in the snow pack, soil, phytome in the active water soluble forms [2] [10] [35] [38] [39] [40].

Taking into account the technogenic load, it is necessary to consider the influence of the gaseous phase substances of the aerosol on the plants; those substances prevail in volume in comparison to the solid emissions from the GRES power plant and, also, are enabled to drift for the longer distances. It was identified earlier that in the investigation zone $\mathrm{SO}_{2}$ content in the open air of the sample areas varies depending on the year; maximum content in the open air was noticed at the distance of $17 \mathrm{~km}$, while GRES power plant nearabout territories were characterised with significantly lower (by 1.5) $\mathrm{SO}_{2}$ content [10].

Thus, suspended substance (smoke emissions components insoluble in the 
snow water) content significative sets technogenic pollution gradient of the snow pack in the transect limits in the south-west direction from the RGpp. Sum concentration of the water soluble substances of the dry residue is the least on the nearest to the GRES power plant and the most distant snow trials sampling points. $\mathrm{pH}$ index meaning of the snow water decreases with a longer diastance from the source of air pollutants.

Condition of the pine male generative system. The mature pollen studied on the light-optical level features monomorphic type. Stated earlier by us and other authors, features variabilty of the body and air pockets length and height, exine developmental stage depends on the male gametophyte developmental stage, genotype and, also growing conditions. Other morph types: 1.3, and more air pockets, abnormal air pockets (abortive, rumpled), "giant” pollen grains (diads), "reduced" (small-sized) were determined as teratomorphic and sterile, due to their $100 \%$ not-germination on the nutrients, even if they preserve functional activity at the early stages of microgametogenesis [20]. Pollen grains of typical morphology with cytological cell distortions, with changed amount of cells and not having reserve substances were also referred as sterile.

Dynamic pattern of some pine male generative system significatives in the technogenic pollution gradient is represented in Figures 6-8. Mann-Whitney and Cruskal-Wallace nonparametric criteria were applied to identify the differences between the SA. Significatives, those were found unimportant in the terms of difference between the SA, were eliminated from the list. Correlation analysis was performed to examine the correlation between the pine pollen significatives.

It was identified that average meanings of the pollen fertility and reserve substances content in the mature pollen (Figure 6) among the population changes similarly in the technogenic pollution gradient: decrease at the longer distance from the source of air pollutants in series SA-1 > SA-2 > SA-3, and increase to the level of SA-1 in the background tree stand. Significatives of the pollen germination on the nutrients change in the alter way: increases at the longer distance from the source of air pollutants in direction SA-1 $<$ SA-2 $<$ SA-3, then decrease to the meanings of SA-1. The differences between the SA-3 and other SA are authentically valuable $(\mathrm{p}<0.05)$ in the most stated significatives.

Mainly, pollen grains with cytological distortions $(45.01 \%-78.29 \%$ from

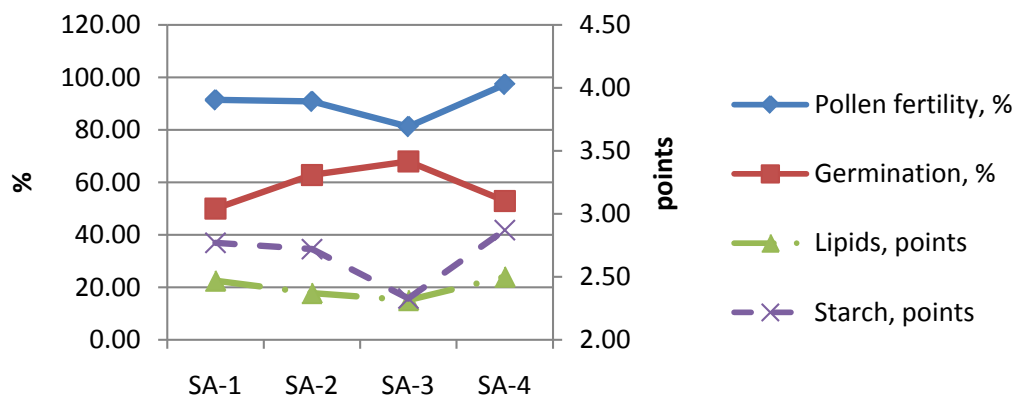

Figure 6. Pollen fertility, germination and presence of reserve substances in the pine pollen. 
amount of the sterile pollen) contribute to the pine pollen sterility, apart from SA-4, where small-sized pollen grains contribution $(40.64 \%)$ is a bit higher. Significatives of frequency meanings of the small-sized pollen grains (the differences between SA-1 and SA-4 are 4.6 times) and sums of pollen grains with morphological abnormalities (3.1 times) decrease significantly at the longer distance from the source of air pollutants (Figure 7).

Pollen tube length significative varies independently the distance from the source of air pollutants (Figure 8) and has maximum meanings for the SA-2 pollen (the differences with SA-1 are authentically correct with $\mathrm{p}<0.05$ ). However, it is worth mentioning that variation coefficient of the pollen vital capacity in SA-2 increases to $19.3 \%$ against $7.6 \%-10.1 \%$ in the other SA due to the particular trees in SA-2 forming pollen tubes with low vital capacity (1.5 - 2 scores).

Significatives discussed above are traditional in studying conifers pollen quality. Also, we additionally evaluate the significatives of pollen tubes branching and fungal mycelium development on the pollen specimen, those allow to evaluate pollen tubes vital capacity more objectively.

Pine pollen tube branching while germination on the micropyle seedbud is a normal phenomenon and is considered by the researchers as a way of enlarging of pollen tube haustorial function and its ability to metabolism with seedbud tissues. While sprouting of the pine pollen in vitro on the distilled water as a nutrient typical, normally developing and growing pollen tubes do not branch or have 1 - 2 branches. However, in some cases of at the early stages of pollen tube development (with pollen tube length $80-120 \mathrm{mkm}$ ), we observed an "antlers" type intensive branching of the pollen tubes, that was accompanied by the halt in growth and development of pollen tubes and, also, an intensive starch accumulation on the nutrients with high content of sucrose (3\% and more). Due to the stated earlier we consider intensive branching of the pollen tube ( 3 - 4 scores) as an indicator of its low vital and competition capacity. It was discovered that meaning of the pollen tube branching significative authentically decrease at the longer distance from the source of air pollutants $(r=-0.39)$ (see Figure 8).

The permanent problem of the trial is the infection of the germinating pollen specimen with fungus spores and mycelium development. Developing pine pollen tubes is the natural factor of fungus development suppression on the pollen specimen: as a rule, an intensive floccus development pollen specimen as ob-

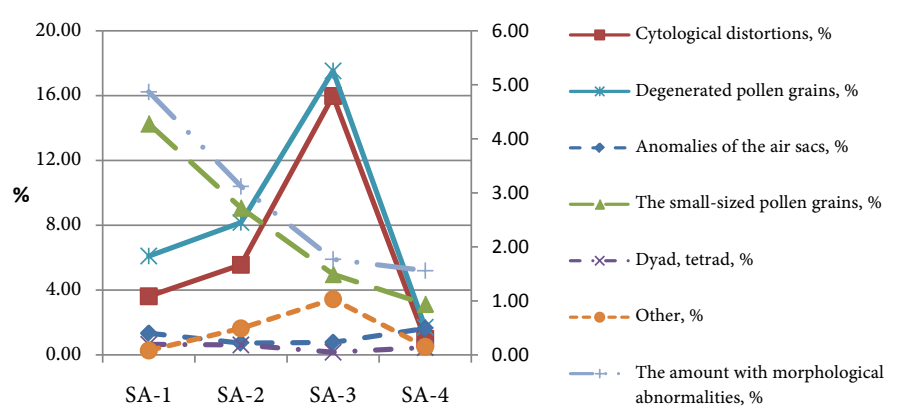

Figure 7. Spectrum of the pine pollen abnormalities (\% of the examined pollen grains). 


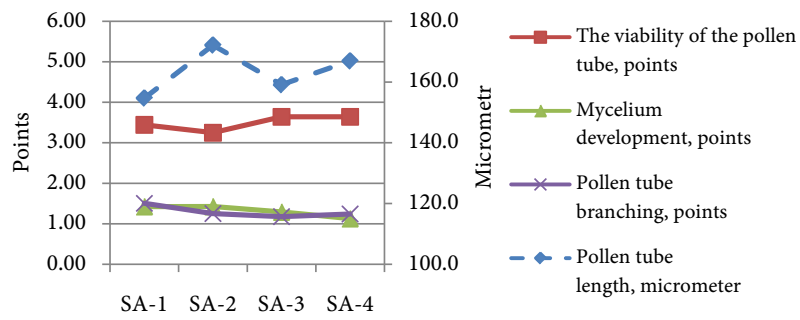

Figure 8. Functional pine pollen indicators.

served in cases when the amount of germinating pollen grains was small or poor growth of pollen tubes [20]. We suppose high-priority and defining influence exactly of pollen tubes on the mycelium development. This is proved with the correlation between significatives of germination and fungus development $(\mathrm{r}=$ -0.42 ), because pine pollen imbibition and germination in vitro start in the first hours of the trial when the impact of fungus spores and mycelium is minimal. Probably, further developing mycelium may has an inhibitory effect on pollen tubes growth, that is shown as the presence of negatively related correlation between the fungus development and pollen tube length $(r=-0.27)$ and its vital capacity $(r=-0.71)$ significatives. In some cases, we observed pollen tube tolerance to the fungus on the specimen that was exhibited with an intensive growth and development of the pollen tube almost in contact with the mycelium. We considered pollen tubes ability to resist the fungus development as a part of the specific pollen sustainability to the millieu factor and genotype competitive advantage. Decrease of fungal mycelium development significative on the pollen specimen at the longer distance from the air pollutants source (see Figure 8) proves indirectly increase of pollen vital capacity in SA-3 and SA-4.

Thus, the average in population meanings for small-sized pollen grains frequency, pollen grains sums with morphological abnormalities, fungus development on the germinating pollen and, also, pollen tubes branching significatives decrease at the longer distance from the source of air pollutants. There is a nonlinear correlation between the significative if the distance from the air pollutants source and the other significatives of the pine male generative system.

\subsection{SA Comparative Characteristic in Conjunction with the Significatives of the Male Generative System}

It was discovered that pine pollen from the trees of the GRES power plant impact zone, growing on the ash-disposal area, has high similarity to the qualitative and quantitative significatives of the pollen from the background tree stand. Thus wise, in comparison to other SA, the pollen from both tree stands features high meanings of pollen fertility and reserve substances content and also high amount of pollen with intensive ( 3 and more scores) starch accumulation accompanied with lower meanings of pollen germination on the nutrient. The similarity between SA-1 and SA-4 was also indicated in the abnormalities spectrum of the mature pollen: in comparison to other tree stands, pollen grains with cytological distortions makes less contribution to the sterility, while small-sized 
pollen grains, pollen grains with abnormal air pockets and also diads and tetrads make a bigger contribution. However small-sized pollen grains and pollen grains with cytological distortions frequency is higher in SA-1 than in SA-4, correspondingly, 4.5 and 3.7 times (see Figure 7). Authentically meaningful differences between the SA-1 and SA- 4 were discovered in the significatives of fungus development and degenerated pollen grains frequency $(\mathrm{p}<0.05)$.

Research results prove that abnormal male gametophyte elimination in SA-1 takes place at the stage of pollen germination as well as at the stage of pollen tube development. Abnormal male gametophyte elimination in the tree stands from the background conditions takes place mainly at the stage of pollen germination; mature pollen tubes of the pollen from the background tree stand are longer more viable than pollen tubes from SA-1.

The research results show significant differences between tree stand pollen at the distance of $9 \mathrm{~km}$ from the air pollutants source and other tree stands pollen. For SA-3 pollen lower meaning for fertility and reserve substances content significatives were discovered, but higher for pollen germination pollen tube vital capacity significatives. Pollen grains with cytological distortions prevail in the SA-3 pollen abnormalities spectrum. Their frequency exceeds $2.8-16.3$ times in comparison to the other SA. The differences between the SA-3 and the other tree stands are authentically valuable in many pollen quality significatives $(\mathrm{p}<0.05)$. Thus, with the less amount of the fertile pollen, the decrease $1.5-1.6$ times of pollen amount with high ( 3 and more numbers) starch content, in comparison to other tree stands, SA-3 fertile pollen has high meanings of germination and pollen tube quality. Even small amount of the starch grains is enough for the SA-3 pine pollen germination on the nutrient. SA-3 abnormal male gametophyte eliminate mainly at the early stages of microgametogenesis-in the pollen grain development process, that is seen in the lowering of pollen fertility significative. SA-3 mature pollen has high meanings of germination and vital capacity significatives. SA-3 pollen tubes length is marginally less than in the SA-2 pollen that may be in particular correlated with the less content of the reserve substances in SA-3 pollen. The following fact directs attention; SA-3 varies from the other SA in 11 - 12 pollen significatives, while other SA differs in pairs only in 2 - 3 significatives. It is also worth mentioning that, in comparison to the other SA, individual level of SA-3 pollen variability is higher in the significatives of pollen fertility (17.9\%) and starch content (up to $46.6 \%$ ), and has positive correlation between the fertility, germination and pollen tubes length significatives of the tree stand. Thus wise, pollen from the particular trees in SA-3 with low meaning of the fertility significative has a strong probability to have low meanings of the germination and pollen tubes length significatives.

Structural and functional significatives of SA-2 pollen in many circumstances take the in between meanings of the SA-1 and SA-3.The following regularities are worth mentioning. With meanings equal to SA-1 in terms of pollen fertility significative and marginally lower reserve substances content, SA-2 pollen has authentically higher meanings of germination and pollen tubes length $(\mathrm{p}<0.05)$. 
The following results were acquired comparing SA-2 and SA-3 pollen: pollen fertility, reserve substances and pollen tubes length are authentically higher for SA-2 pollen, while germination is higher for SA-3 pollen.

Scots pine tree stand growing on the ash-disposal area at the distance of 1.5 $2.0 \mathrm{~km}$ from the RGpp (SA-1) is of particular interest for research. The tree stand is influenced with strong atmospheric smoke pollution, the root system develops in the ash substrate, long term water stagnation is observed on the ground during the snow melt in spring. Nevertheless, these conditions do not inhibit pine growth and development. Particular trees ( 20\%) form male and / or female generative structures. Subsequent reproduction is observed under the crown layer. A group of bions ( $\sim 56 \%)$ producing pollen with high, comparable to specific level, meanings of pollen structural and functional significativesfertility, germination and pollen tubes length-were distinguished by us among the model trees in the crops in the ash-disposal area.

Qualitative and quantitative composition of air pollutants might be a valid factor for the development of Scots pine male generative system. Conjugated analysis of the snow water chemical composition and the quality of pine mature pollen in SA was performed to verify this supposition.

\subsection{Pine Pollen Quality Significatives in Correlation with the Level of Snow Pack Technogenic Pollution}

According to the correlation analysis of average population meanings of pine male generative system significatives and the pollutants content in the snow water the following results were indicated. With increasing sum of macro elements and nickel compounds concentration in the snow water the decrease in the meanings of pollen fertility and starch content in pollen grains $(r=-0.97-$ $-1.00)$ significatives was observed, the increase-in pollen grains with cytological distortions and degenerated pollen grains frequency $(r=0.98-1.00)$.

It was discovered that the meanings of pollen tubes length significative reduce with increase of sum of micro elements in the snow water $(r=-0.95)$ and also with increase of the rise of lead content in the snow water suspended substance $(\mathrm{r}=-0.97)$. Diads and small-sized pollen grains frequency increases with the rising of cadmium and copper compounds in the suspended substance, correspondingly $(r=0.96)$. Small-sized PG frequency significative is connected to the dry feces $(r=-0.84)$ and suspended substance $(r=0.93)$ content in the snow water.

Sample areas SA-2 and SA-3, earlier referred by us to the bufer zone according to the characteristics of the technogenic pollution; significantly vary between themselves in the condition significatives of the male generative system. Stated features might be the result of the differences between the SA in terms of micro and macro elements sums in the snow water (by 25 and $11 \%$ correspondingly).

Results of the conducted research prove that the most important significatives of the pine pollen quality are negatively related to the content of macro elements sum (pollen fertility, reserve substances in the pollen) and micro elements sum 
in snow water (pollen tubes length).

\section{Conclusions}

In the impact area, smoke emissions from the RGpp in the south-west direction zones of technogenic pollution were formed. Those vary in qualitative composition of the snow pack pollutants and their quantitative characteristics. Performed studies allowed identifying the wide range of smoke emissions substances, accumulated in the snow cover, and the difference in their composition at the various distance from the aero pollutants.

The highest content of water soluble compounds in the melt snow water was indicated at the distances of 5, 8 and $14 \mathrm{~km}$ from the source of air pollutants authentically lower in the nearest and farthest sampling points of the snow trials. Probably, stated regularity depends on the possibility of atmospheric release of submicron smoke gases particles enriched in heavy metals through the large distances and their further sedimentation on the surface of the snow cover or absorbation with the particles of the atmospheric precipitation. Further, aeropollutants accumulated in the snow cover, reach the soil and after that plants. The processes of pine microsporogenesis and gametogenesis in Ural are associated with April-May and fall in the same time interval with snowmelt period, flux of snowmelt substance into the soil solution and intensive water absorption by the tree roots. For high concentration and mobility of water soluble substances in the soil, their toxicity for the plants could be the causes of pine microgametogenesis disturbance in metabolism process, widening the range of pollen anomalies and frequency increasing pollen with cytological disturbance at the distances of 5 - $8 \mathrm{~km}$ from the source of AP. Shown regularities are proved with correlation relationships between the characteristics of the technogenic pollution and pollen significatives. Thus, dry feces and suspended matter content in the snow water diagnose small-sized PG frequency significative $(r=-0.84$ and 0.93 correspondingly). $33 \%$ of significatives under the study were stated authentically meaningful correlation relationships with the sum meanings of the macro elements and nickel in the snow water. Pollen fertility, pollen tube length and reserve substances' content significatives are negatively related to the presence of microand macroelements in the snow water.

It was indicated that while approaching source of the aero pollutants water insoluble compounds content in the snow water, compiling suspended substance increases, as well as the level of the technogenic pollution in whole, which is defined by the sum of the suspended substance and dry feces. It was indicated that frequency significative meanings of the pollen with morphological anomalies increase, and pollen functional significatives meanings decrease in the technogenic pollution gradient.

It was detected that pine male gametophyte' elimination, while forming in the impact zone of the GRES power plant, takes place at the stage of pollen grain germination as well as pollen tubes growth stage. Pollen tubes forming in the SA-1 pollen are retarded in the terms of growth and have low meanings of the 
functional characteristics in comparison to the other tree stands pollens. Elimination of abnormal and non-adaptive gametophyte of pine tree stand at the distance of $9 \mathrm{~km}$ from the GRES power plant mainly takes at the stage of pollen grain development that is represented in the significant decrease of pollen fertility and reserve substances' content characteristics. Nevertheless, SA-3 mature fertile pollen grains feature authentically higher meanings of functional significatives in comparison to SA-1 pollen. It is worth mentioning that SA pollen germination takes place even if the meanings of starch and lipids content in the pollen are authentically lower in comparison to the other tree stands. Comparing tree stands growing in the technogenic pollution areas, the pollen of the tree stand at the distance of $5 \mathrm{~km}$ from the air pollutants source features higher meanings of morphological and functional characteristics. Consequently, pine male generative system under the conditions of technogenic pollution features structural-functional peculiarities; those might have the adaptive meaning and allow pine pollen from the zones of technogenic pollution to take part in the reproduction process.

Thus, complexity of GRES aerosol emissions, possibility of their transmission for the large distance and irregularity of their fallout, and also long-term period of pine male gametophyte development result in the toxic and mutagenous impact.

Indicated correlation relationships between the technigenic pollution characteristics and pollen significatives demonstrate the possibility of bioindication level and technogenic pollution type with the male generative system significatives. Small-sized pollen grains frequency and pollen grains with cytological disturbance significatives in the entirety of the mature pollen could be recommended for the bioindication of the technogenic pollution from the GRES ash emissions.

Pollen germination significatives could be recommended for the male gametophyte adequacy that allows indicating the non-implemented at the stages of microsporogenesis and microgametogenesis disturbance in the male generative system.

The destiny of substances accumulated in the snow pack depends on numerous factors. Partly, they might be included in the "soil-plant" system and directly or indirecly influence the generative system's development. Further study of the structure connections in the system "atmosphere-snow pack-soil-plant" will encourage the understanding of pollutants transformation, damage and sustainability of arboreal plant mechanisms, conditions of their effective reproduction.

\section{References}

[1] Russian Economics, Numbers and Facts. Part 7. Energetics. Russian Federation Energetic Complex Structure.

http://utmagazine.ru/posts/10560-ekonomika-rossii-cifry-i-fakty-chast-7-energetika

[2] Grishantseva, E.S., Safronova, N.S. and Kirpichnikova, N.V. (2012) Influence of the Atmospheric Emissions Konakovsk GRES Power Plant on the Snow Pack Condition in the Area of Ivankovskoe Dam Lake. Geo-Ecology. Geo-Engineering. Hydrogeol- 
ogy. Geocryology, 2, 135-142.

[3] Scannapieco, D., Naddeo, V. and Belgiorno, V. (2014) Sustainable Power Plants: A Support Tool for the Analysis of Alternatives. Land Use Policy, 36, 478-484.

[4] Guttikunda, S.K. and Jawahar, P. (2014) Atmospheric Emissions and Pollution from the Coal-Fired Thermal Power Plants in India. Atmospheric Environment, 92, 449460.

[5] Ancora, M.P., Zhang, L., Wang, S., Schreifels, J. and Hao, J. (2015) Economic Analysis of Atmospheric Mercury Emission Control for Coal-Fired Power Plants in China. Journal of Environmental Sciences, 33, 125-134.

[6] Anonymous (2015) State Report on Condition and on Environmental Protection of Russian Federation in 2014. M, 473. http://www.mnr.gov.ru/upload/iblock/b27/gosdoklad_2015.pdf

[7] Krylov, D.A. and Sidorova, G.P. (2015) Ecological Influence of the Coal Thermal Power Plants of Russia on the Environment Revised. Energy: Economics, Machines, Ecology, 12, 2-11.

[8] Anonymous (2015) State Report on Condition and on Environmental Protection of Sverdlovsk Region in 2014. Yekaterinburg. http://www.mnr.gov.ru/upload/iblock/3f1/doklad_2014.pdf

[9] Makhnev, A.K., Tchibrick, T.S., Trubina, M.R., Lukina, N.V., Gebel, N.E., Terin, A.A., Elovikov, U.I. and Toporkov, N.V. (2002) Ecological Basis and Methods of Biological Recultivation of Thermal Electric Power Stations Ash-Disposal Areas in the Ural. Yekaterinburg, UB RAS.

[10] Menschikov, S.L. and Ivshin, A.P. (2006) Forest-Tundra and Taiga Transformation Regularities under the Conditions of Technogenic Pollution. Yekaterinburg, UB RAS.

[11] Anonymous (2011) State Report on Condition and on Environmental Protection of Sverdlovsk Region in 2010. Yekaterinburg. http://mprso.midural.ru/arti cle/show/id/1084

[12] Schubert, R., Ed. (1988) Bioindication of the Terrain Ecosystems. Moscow.

[13] Rozhkov, A.S. and Mikhailova, T.A. (1989) The Influence of Fluorine-Containing Emissions on Conifer Trees. Novosibirsk.

[14] Sazonova, T.A., Bolondinskiy, V.K. and Pridacha, V.B. (2011) Scots Pine EcologicalPhisiological Characteristics. Petrozavodsk.

[15] Gallego, S.M., Pena, L.B., Barcia, R.A., Azpilicueta, C.E., Iannone, M.F., Rosales, E.P., Zawoznik, M.S., Groppa, M.D. and Benavides, M.P. (2012) Unravelling Cadmium Toxicity and Tolerance in Plants: Insight into Regulatory Mechanisms (Review). Environmental and Experimental Botany, 83, 33-46.

[16] Mendoza, R.E., García, I.V., Cabo, L., Weigandt, C.F. and Iorio, A.F. (2015) The Interaction of Heavy Metals and Nutrients Present in Soil and Native Plants with Arbuscular Mycorrhizae on the Riverside in the Matanza-Riachuelo River Basin (Argentina). Science of the Total Environment, 505, 555-564.

[17] Skripalschikova, L.N., Dneprovskiy, I.A., Stasova, V.V., Pliashechnik, M.A., Greshilova, N.V. and Kalugina, O.V. (2016) Scots Pine Acerose Leaf MorphologyAnatomic Peculiarities under the Influence of Krasnoyarsk City Industrial Emissions. Siberian Journal of Forest Science, 3, 46-56.

[18] Galibina, N.A. and Terebova, E.N. (2008) Peculiarities of the Acerose Leaf Cells Wall Characteristics of the Healthy and Weaken Scots Pine Plants. Physiology of Plants, 55, 419-425.

[19] Zaytsev, V.F. and Galyamova, G.K. (2012) Content and Distribution Peculiarities of 
Heavy Metals $(\mathrm{Cu}, \mathrm{Zn}, \mathrm{Cd}, \mathrm{Pb})$ in the System "Soil-Fir-Needle and Leaves of Woody Species" in the Different Areas of Ust-Kamenogorsk City. South Russia: Ecology, Development, 4, 66-71.

[20] Makhniova, S.G., Babushkina, L.G. and Zueva, G.V. (2003) Condition of Scots Pine Male Generative Sphere under the Environment of Technogenic Pollution. Yekaterinburg, USFEA, Ural University Publishing House.

[21] Tretyakova, I.N. and Noskova, N.E. (2004) Scots Pine Pollen under the Conditions of Ecological Stress. Ecology, 1, 26-34.

[22] Djuba, O.F. (2006) Palynology Indication of the Environment Quality. St. Petersburg.

[23] Kalashnik, N.A., Yasovieva, S.M. and Presnukhina, L.P. (2008) Pine Trees Pollen Abnormalities under the Conditions of Industrial Pollution in the South Ural. Forest Science, 2, 33-40.

[24] Sadakova, K.A. and Kolyasnikova, N.L. (2014) Pollen Grains Fertility and Heavy Metals Content Scots Pine Pollen Growing in the Areas with Different Anthropogenic Load. Contemporary Problems of Science and Education, 6, 1-14.

[25] Vasilevskaya, N.V. and Petrova, N.V. (2014) Pollen Morphological Variiability Pinus sylvestris L. under the Conditions of City (Case Study Monchegorsk City). Bulletin of Petrazavodsk State University, 4, 7-12.

[26] Chropenová, M., Gregusková, E.K., Karáskováa, P., Pribylová, P., Kukucka, P., Barákováa, D. and Cupr, P. (2016) Pine Needles and Pollen Grains of Pinus mugo (Turra.)-A Biomonitoring Tool in High Mountain Habitats Identifying Environmental Contamination. Ecological Indicators, 66, 132-142.

[27] Martynov, A.I., Ilyina, N.I., Luss, L.V., Martynov, A.A., Fedoskova, T.G. and Andreev, I.V. (2011) Peculiarities of Pollen Characteristics in the Regions of Chemical Factor. Russian Allergology Journal, 6, 12-16.

[28] Reshetova, S.A., Solodukhina, M.A. and Yurgenson, G.A. (2015) The Interrelation between Pollen Abnormalities and Polymorphism and the Increased Contents of Toxic Elements in Flowers and Flower Buds in Aconogonon angustifolium (Pall.) Hara. and Papaver nudicaule L. Russian Journal of Ecology, 46, 36-42. https://doi.org/10.1134/s1067413615010142

[29] Ivanov, A.I., Stacenko, A.P., Selina, E.E. and Skobaneva, O.V. (2009) Use of Woody and Herbal Plants Pollen for Bioindication of Environment Pollution. Vestnik of FEB RAS, 6, 68-73.

[30] Kolyasnikova, N.L., Karnazhitskaya, T.D. and Parshakova, K.A. (2011) Influence of Aerotechnogenic Pollution on the Morphological and Embryological Characteristics of Pine. Bulletin of Udmurt University. Biology \& Earth Sciences, No. 2, 31-35. http://ru.vestnik.udsu.ru/archive/show/6-2011-2-4

[31] Kolesnikov, B.P. (1969) Forests of Sverdlovsk Region. Forests of the USSR, 4, 64124.

[32] Anonymous (1991) Atmosphere Pollution Control Guide. RD 52.04.186-89, Moscow.

[33] Pausheva, Z.P. (1988) Plants Cytology Practical Work. Moscow.

[34] Lebedeva, L.N., Kortsenshtein, N.M. and Samuylov, E.V. (2014) Thermodynamic Analysis of Submicrone Particles Emissions Probability While Coal Burning. Thermal Power, 12, 70.

[35] Gluschenko, N.N. and Olkhovskaya, I.P. (2014) Ecological Safety of the Power Industry. Characteristics of Ash Dust from Thermal Power Plants, Using Coal. Proceedings of the Russian Academy of Sciences, Power Engineering, 1, 20-28. 
[36] Kizilshtein, L.Ya. and Levchenko, S.V. (2014) Ecologically Dangerous Concentrations of Recrement Elements in the Some Coal Basins and Deposits of Russia. Proceedings of Higher Educational Establishments, Geology and Exploration.

http://i.uran.ru/webcab/system/files/journalspdf/izvestiya-vuzov.ser.geologiya-i-raz vedka/izvestiya-vuzov.ser.geologiya-i-razvedka-2014-n-3/georaz32014.pdf

[37] Chen, J., Liu, G., Kang, Y., Wu, B., Sun, R., Zhou, C. and Wu, D. (2013) Atmospheric Emissions of F, As, Se, Hg, and Sb from Coal-Fired Power and Heat Generation in China. Chemosphere, 90, 1925-1932.

[38] Minkina, T.M., Motuzova, G.V., Miroshnichenko, N.N., Fateev, A.I. and Mandzhieva, S.S. (2013) Heavy Metals Accumulation and Distribution. Agrochemistry, 9 , 65-75.

[39] Saikia, B.K., Hower, J.C., Hood, M.M., Baruah, R., Dekaboruah, H.P., Boruah, R., Sharma, A. and Baruah, B.P. (2015) Petrological and Biological Studies on Some Fly and Bottom Ashes Collected at Different Times from an Indian Coal-Based Captive Power Plant. Fuel, 158, 572-581.

[40] Zhu, C., Tian, H., Cheng, K., Liu, K., Wang, K., Hua, S., Gao, J. and Zhou, J. (2016) Potentials of Whole Process Control of Heavy Metals Emissions from Coal-Fired Power Plants in China. Journal of Cleaner Production, 114, 343-351.

\section{Submit or recommend next manuscript to SCIRP and we will provide best} service for you:

Accepting pre-submission inquiries through Email, Facebook, LinkedIn, Twitter, etc. A wide selection of journals (inclusive of 9 subjects, more than 200 journals)

Providing 24-hour high-quality service

User-friendly online submission system

Fair and swift peer-review system

Efficient typesetting and proofreading procedure

Display of the result of downloads and visits, as well as the number of cited articles

Maximum dissemination of your research work

Submit your manuscript at: http://papersubmission.scirp.org/

Or contact gep@scirp.org 